\title{
MEME COMIC AS THE DEVELOPING MEDIA OF SPEAKING FOR STUDENTS IN JUNIOR HIGH SCHOOL
}

\author{
*Muhammad Arif Sanjaya \\ **Rahmad Husein \\ **Maya Oktora
}

\begin{abstract}
This research was aimed to develop appropriate, interesting and attractive speaking media in teaching descriptive text for seventh grade students of MTsS UMMI Lubuk Pakam. Due to the result in the form of product, this study was categorized as Research and Development (R \& D) study which adapted from Borg and Gall (1989) theory with some modifications. The subject of this study was the seventh grade students of MTsS UMMI Lubuk Pakam. In conducting this research, the procedures were gathering the data and information, conducting the need analysis, designing the first draft of media, revising the media, and producing the final product as the meme comic. The instruments of collecting data were the combination of two strategies; interview and questionnaires. The interview result was analyzed as qualitative data and the questionnaires analyzed as quantitative data. These data were needs of students covering target needs and learning needs. This study developed speaking media which only focused on descriptive text taught in the odd semester. These media was based on Curriculum 2013.
\end{abstract}

Keywords : Developing speaking media, seventh grade students, descriptive text, Meme Comic.

*Graduate Status
$* *$ Lecturer Status 


\section{INTRODUCTION}

\section{Background of the Study}

Speaking is one of important skills which is needed in learning English. As Richard points out (2008), speaking in a second and foreign language has often been viewed as the most demanding of the four skills. The skill which is categorized as an important skill must be developed well in order to increase the ability and capability of the students. By speaking, students are able to interact and communicate with both student and teacher. (Fulcher, 2003) state that speaking is the verbal use of language to communicate with others. Based on that statement speaking is a tools to communicate and express our feeling or thought to others, with speaking we can explain and express many things that we want to tell much more than other communication tools like writing, body gesture and etc.

In fact, many students feel difficult to apply speaking in the learning process nowadays. This becomes one of the reasons why their ability in speaking is not developed at school. They feel worried so much that they will make some mistakes during speaking. That actually makes them less contribute in speaking learning process. They would rather to keep silent than to speak during the English learning process. It always happens the most in almost all Junior High School students in Indonesia.

Based on the Indonesia curriculum, there are many kinds of genre which is really needed to be learnt by the students. They are descriptive, recount, narrative, report, and also procedure text. 
Descriptive text is one of the genre that aims to describe something such as people, things, animals, places and many others. Most of the activities in learning descriptive just focus on writing skills that means students just know how to write the descriptive text on a piece of paper not in spoken. That becomes problem because it should be taught not only in written form but also spoken form.

In order to make them easy to describe the things orally, there must be such media supported as pictures, flash cards, videos and many more. The failure of choosing the media in learning will drive the students to the wrong way to reach the aims of the learning. That is why media is so important that helps teacher as well as student during the learning process.

But, the fact shows that there is no an interesting media used in learning speaking, especially in learning descriptive text orally. It is proven by the primary observation done by the researcher in MTsS UMMI Lubuk Pakam showing that media of speaking used for the students does not really motivate the students to learn and even does not elaborate students' ideas in describing the things orally. It is proven by the data taken by the researcher in which one of the media of teaching speaking that the teacher used:
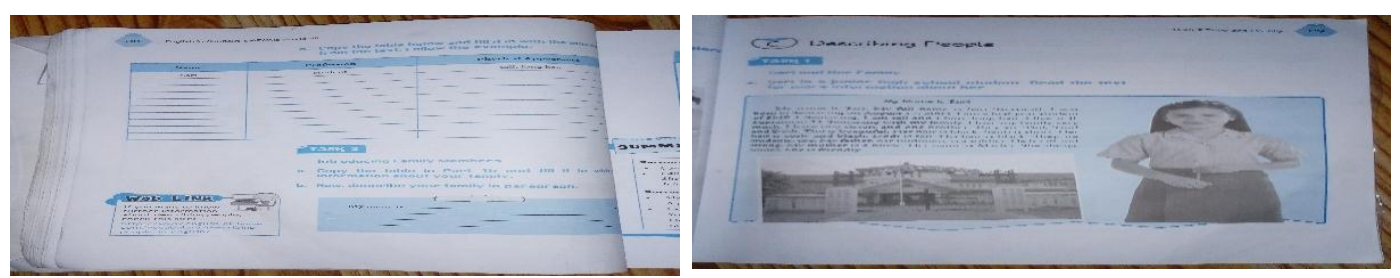

Figure 1.1. The media that are used by teacher to teach descriptive text. 
Speaking activity such as describing something could be easier done by students by using media. Without the media which could stimulate them to speak, it would be such a difficult thing and they would not really care about the learning process. As the result, the classroom situation would not be active and the goal of the teaching learning process will not be achieved. (Macwan, 2015) stated that Visual aids can help in speaking activities as learners will share their feelings and inspirations. They provide the learners with the opportunity to speak in order to develop their speaking skills.

In this research, the researcher puts fully concern to $7^{\text {th }}$ grade of Junior High School students. The students complained that speaking in English is quite difficult especially describing something in English. As the result, they always keep silent and doing nothing during the speaking learning process. Due to the lack ability of students to improve their speaking skill, the goal of teaching and learning process in descriptive text in spoken form will never be achieved. Then, it will not run effectively in teaching and learning process.

The only one solution for this problem is creating a meme comic as the developing media which is interesting and innovative in guiding the students to speak as well as describe something orally which focus on speaking skill for students of MTsS UMMI Lubuk Pakam. The development of the media must attract as well as stimulate their willingness to speak and describe orally any topics related to descriptive text which hopefully will increase the students' motivation and enthusiasm to learn any material in English subject. Finally, it will improve the English skills of Junior High School students. 


\section{REVIEW OF RELATED LITERATURE}

Theoritical Framework

Burns \& Joyce (1997) and Luoma (2004:2) define speaking as an interactive process of constructing meaning that involves producing, receiving, and processing information. Thus, it can be comprehended that speaking is the productive activity which is actually the verbal use of language which has function to express ideas, thoughts, or opinions among two or more people who are engaged in communicating or talking to each other.

A meme (/MIM/mim) is "ideas, behaviors, or style that spread from person to person in the culture"(Dawkins,1989). A meme is a picture which brings cultural ideas, symbols or practices that can be transmitted from one mind to another through writing, speech, gestures, rituals or other imitable phenomena, with a specific theme. Gavigan \& Tomasevich (2011) states that comic is a medium of literature that integrates pictures and words and arranges them cumulatively to tell a story or convey information which can be humorous, mysterious, etc. This definition adds the idea of comic being literature and highlights its cumulative nature.

From some previous definitions, it can be concluded that meme comic is an art work which is pictures that each of it has some characters, events, ideas, which tell a story or convey information as well as display a distinctive character which express certain feelings, sarcasms, humors, satires and it usually takes place on books or newspaper and internet. 


\section{Conceptual Framework}

In teaching-learning process, media is a crucial element needed by the students. From the media, students can absorb the knowledge and explore their language skills. It also supports the students in Junior High School which basically the beginner learner. The students need a media to help as well as motivate them to think and speak anything in describing something related to the descriptive text genre. It means that the media in teaching-learning process must be interesting in order to motivate the students and ease them to learn speaking English. Based on the researcher's observation, the researcher found that there were no teachers who used the media to teach. So, the students do not have motivation to study without any media that support them.

As the solution of this problem, the researcher developed Meme Comic as the media to teach speaking in descriptive text genre or oral descriptive text. This Meme Comic is a funny picture of people with the caption which tells the physical appearances of the people. In the picture, the students were asked to describe and made any description based on the people's appearances shown in the Meme Comic. In that way, it eased the students to get any ideas regarding to the descriptive text that they will speak or retell in the form of speaking. This recommended media eased the students to comprehend and to speak any oral descriptive text as well as motivated them to learn English more. 


\section{RESEARCH METHODOLOGY}

In conducting this research, this research was conducted based on Research and Development method ( $R \& D)$. R \& D is one of research design aimed to develop and validate educational products, such as: curriculum, syllabus, textbooks, instructional media, modules, assessment instrument, etc. (Borg \& Gall, 2003:569). This developmental research consist of six stages, as mentioned below: 1) Gathering information and data. 2) Analyzing data. 3) Designing new materials. 4) Validating new materials by experts. 5) Revising reading materials. 6) Final product.

The subject of this study was the seventh grade students of MTsS UMMI Lubuk Pakam. This subject was chosen because the researcher found the media of speaking used in the school were not really interesting which is not able to improve the students' willingness to learn English. "Buku Bahasa Inggris" published by Pusat Kurikulum dan Perbukuan, Balitbang, Kemendikbud in 2014 used by the students becomes the only one media and material that teachers used in the teaching and learning process. Based on the preliminary observation, the class consisted of 31 students in odd semester.

The data were collected in the form of qualitative and quantitative. The qualitative data were obtained from the questionnaires of the students and the interview of teacher, stakeholder, and some students. While quantitative data were obtained from the questionnaires in form of percentage. These two forms were the references of data analysis. 
Techniques of Analysis Data

The data obtained from the questionnaire and interview were firstly collected and analyzed. These data were needed to evaluate the media of speaking and assess the students' needs in learning speaking especially in oral descriptive text. The data were divided into two forms of data analysis, qualitative data analysis and quantitative data analysis. The data were firstly collected in the table, and then the researcher described the findings. The qualitative data were analyzed by drawing the conclusion of the questionnaire and the interview. Based on the two analyses, the researcher planned the recommended media of speaking.

\section{RESEARCH FINDINGS AND DISCUSSION}

In developing writing media, there were six steps need to be taken, namely (1) Gathering data and information, (2) need analysis, (3) Media design, (4) Validating to experts, (5) Revising, and (6) Final product.

The data and information were firstly derived from the primary observation done before doing the research. The fact showed that the media was really not interesting and cannot attract the students' attention to stimulate them in speaking descriptive text, since speaking is considered as a difficult skill.

The second step was doing the need analysis. The needs must be analyzed before developing the new media. See the following tables: 
1. The students' background of problem

Table 4.1. The students' Ability in speaking descriptive text

\begin{tabular}{lcc}
\hline \multicolumn{1}{c}{ Questions } & Items & Percentage \\
\hline $\begin{array}{l}\text { Do you learn speaking in genre } \\
\text { descriptive text at class? }\end{array}$ & Yes & $100 \%$ \\
\cline { 2 - 3 } & No & $-\%$ \\
\hline
\end{tabular}

Table 4.2. The students' experience in learning speaking descriptive text

\begin{tabular}{lcc}
\hline \multicolumn{1}{c}{ Questions } & Items & Percentage \\
\hline $\begin{array}{l}\text { Have you ever got some difficulties in learning } \\
\text { speaking in genre descriptive text? }\end{array}$ & Yes & $93,6 \%$ \\
\cline { 2 - 3 } & No & $6,4 \%$ \\
\hline
\end{tabular}

Table 4.3. The teacher's media

\begin{tabular}{lcc}
\hline \multicolumn{1}{c}{ Questions } & Items & Percentage \\
\hline $\begin{array}{l}\text { Does your English teacher use such media while } \\
\text { teaching speaking in genre descriptive text? }\end{array}$ & Yes & $100 \%$ \\
\cline { 2 - 3 } & No & $-\%$ \\
\hline
\end{tabular}

Table 4.4. The students' knowledge about Meme Comic

\begin{tabular}{|c|c|c|}
\hline Questions & Items & Precentage \\
\hline \multirow[t]{2}{*}{ Do you know what meme comic is? } & Yes & $83,9 \%$ \\
\hline & No & $16,1 \%$ \\
\hline
\end{tabular}

Based on the tables above, it could be concluded that speaking in genre descriptive text has been learning in the first grade of Junior High School. However, they got difficulties to understand the concept of descriptive text. Not 
only that, they also got difficult in speaking descriptive text. In fact, the problem was due to teacher who infrequently used the media or the media used by the teacher was not really interesting and did not help the students to stimulate them in speaking descriptive text easily. Actually, the teachers only used some pictures and the material from the text book which did not stimulate their willingness to be dare to speak. There should be such an interesting media used by teacher to help them in order to stimulate their mind in speaking descriptive text. In fact, most of the students have known meme comic that will be developed further by the researcher as the media in learning speaking descriptive text.

\section{Target Needs}

The result of target needs covered three terms which are: necessities, lacks and wants. See the following tables:

a. Necessities

Table 4.5. Reason of learning English

\begin{tabular}{llc}
\hline \multicolumn{1}{c}{ Question } & \multicolumn{1}{c}{ Items } & Percentage \\
\hline $\begin{array}{l}\text { What is the reason } \\
\text { that you learn } \\
\text { speaking } \\
\text { descriptive text? }\end{array}$ & \multicolumn{1}{c}{ To be able to speak in English } & $9,6 \%$ \\
\cline { 2 - 3 } & $\begin{array}{l}\text { To be able to explain something in } \\
\text { English }\end{array}$ & $16,3 \%$ \\
\cline { 2 - 3 } & $\begin{array}{l}\text { To be able to describe something in } \\
\text { English }\end{array}$ & $67,7 \%$ \\
& & $6,4 \%$ \\
\hline
\end{tabular}


Table 4.6. The students' need of media

\begin{tabular}{llc}
\hline \multicolumn{1}{c}{ Question } & \multicolumn{1}{c}{ Items } & Percentage \\
\hline $\begin{array}{llc}\text { Do you need media to help you while learning } \\
\text { speaking descriptive text? }\end{array}$ & Yes & $100 \%$ \\
\cline { 2 - 3 } & No & $-\%$ \\
\hline
\end{tabular}

As proposed above, Most of the students thought that the reason why they learn speaking descriptive as their necessities is to be able to describe something in English. This is in line with the social function of descriptive itself. Then all of the students need media to help them in learning speaking descriptive text. Not a mainstream media, but such an interesting media that is able to make them join the learning and easily absorb the material.

b. Lacks

Table 4.7. The Students' tendency in speaking English

\begin{tabular}{llc}
\hline \multicolumn{1}{c}{ Question } & \multicolumn{1}{c}{ Items } & Percentage \\
\hline In speaking English, you tend to be ... & Active & $22,6 \%$ \\
\cline { 2 - 3 } & Passive & $77,4 \%$ \\
\hline
\end{tabular}

Table 4.8. The Students' lacks in learning speaking descriptive text

\begin{tabular}{|c|c|c|}
\hline Question & Items & Percentage \\
\hline \multirow{4}{*}{$\begin{array}{l}\text { You often find the difficulties in learning } \\
\text { speaking descriptive text in which material? }\end{array}$} & Things & $6,4 \%$ \\
\hline & Animals & $12,9 \%$ \\
\hline & People & $80,6 \%$ \\
\hline & Other.... & $-\%$ \\
\hline
\end{tabular}


As mentioned above, most students tends to be passive while learning speaking. It might happen, because there is no such an interesting media to stimulate them to speak. Their lacks also happen due to process of learning English which tends to prefer writing and reading than speaking. That's why they get difficult when they should be asked to speak or describe something orally in genre descriptive text. Then, most students also got the difficulties in describing people more than describing things, animals and others. From those all above, the researcher choose and develop the media on how to describe people.

c. Wants

Table 4.9. The students' wants in learning speaking descriptive text

\begin{tabular}{llc}
\hline \multicolumn{1}{c}{ Question } & \multicolumn{1}{c}{ Items } & Percentage \\
\hline $\begin{array}{llc}\text { In learning speaking descriptive text, you } \\
\text { want the learning media as...... }\end{array}$ & Pictures & $12,9 \%$ \\
\cline { 2 - 3 } & Meme Comic & $71,1 \%$ \\
\cline { 2 - 3 } & Poster & $9,6 \%$ \\
\cline { 2 - 3 } & Other... & $6,4 \%$ \\
\hline
\end{tabular}

From the tables above, the students liked to learn speaking descriptive text by using meme comic. As the consideration that they have been familiar with meme comic on internet. So, it will attract their intention as well as attention to learn speaking descriptive text. It will be such an interesting media that will be fun and suitable to be used in learning speaking descriptive text.

\section{Learning Needs}

The result of learning needs could be seen on the following tables: 
Table 4.10. The students' expectation in learning speaking descriptive text

\begin{tabular}{llc}
\hline \multicolumn{1}{c}{ Question } & \multicolumn{1}{c}{ Items } & Percentage \\
\hline $\begin{array}{l}\text { According to your opinion, if learning } \\
\text { speaking descriptive text uses meme } \\
\text { comic, it will be.... }\end{array}$ & Interesting & $77,6 \%$ \\
\cline { 2 - 3 } & Boring & $9,6 \%$ \\
\cline { 2 - 3 } & Ordinary & $6,4 \%$ \\
\cline { 2 - 3 } & Other... & $6,4 \%$ \\
\hline
\end{tabular}

Table 4.11. The speaking descriptive text media input preference

\begin{tabular}{|c|c|c|}
\hline Question & Items & Percentage \\
\hline \multirow{3}{*}{$\begin{array}{l}\text { You prefer learning English by } \\
\text { using meme comic which } \\
\text { shows }\end{array}$} & Text only & $-\%$ \\
\hline & Picture only & $-\%$ \\
\hline & Text and picture & $100 \%$ \\
\hline
\end{tabular}

Table 4.12. The use of Meme Comic in learning speaking descriptive text

\begin{tabular}{llc}
\hline \multicolumn{1}{c}{ Question } & \multicolumn{1}{c}{ Items } & Percentage \\
\hline $\begin{array}{l}\text { Will using meme comic as the learning media } \\
\text { ease you in the learning process? }\end{array}$ & Yes & $83,9 \%$ \\
\cline { 2 - 3 } & No & $16,1 \%$ \\
\hline
\end{tabular}

Table 4.13. The students' expectation of Meme Comic in learning speaking descriptive text

\begin{tabular}{llc}
\hline \multicolumn{1}{c}{ Question } & \multicolumn{1}{c}{ Items } & Percentage \\
\hline $\begin{array}{l}\text { You expect that meme } \\
\text { comic which is used as a } \\
\text { media in learning }\end{array}$ & Explanation & $6,4 \%$ \\
\cline { 2 - 3 } & Example & $6,4 \%$ \\
\hline
\end{tabular}


speaking descriptive text

Practice

$6,4 \%$

covers.....

All in one

$80,8 \%$

In learning process the students preferred to learn use meme comic which shows the picture and text to be more innovative and interesting. Then, they thought that meme comic was more helpful and ease them to understand the concept of descriptive text for them as well as to practice speaking descriptive text. Students will learn speaking descriptive text by using meme comic which covers the explanation of descriptive text, the example of descriptive and the practice to test their understanding about descriptive text and to test their speaking ability in descriptive text.

Referring need analysis as the basis to design the new materials, the final product after being validated and revised was developed as follow:

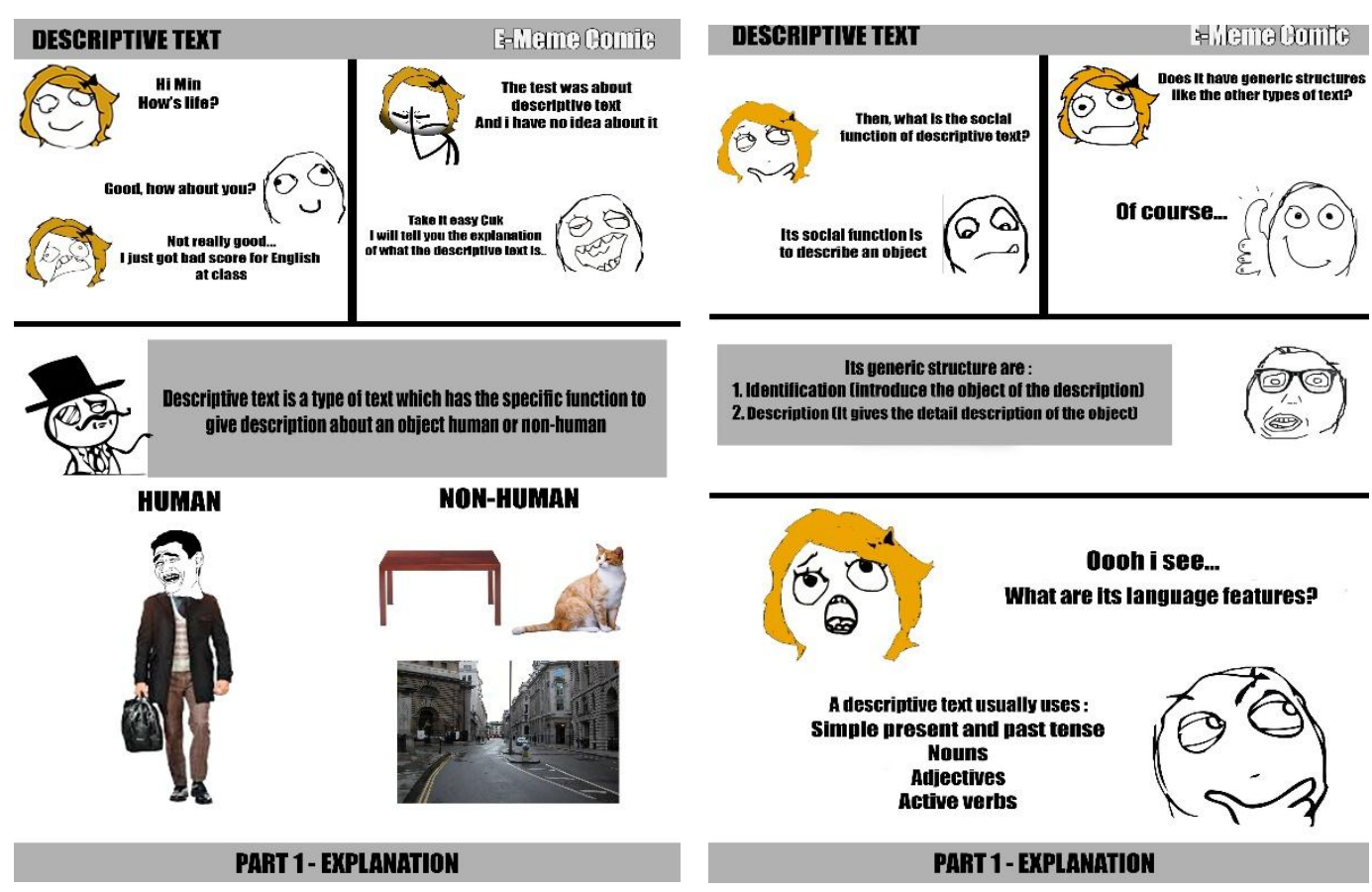



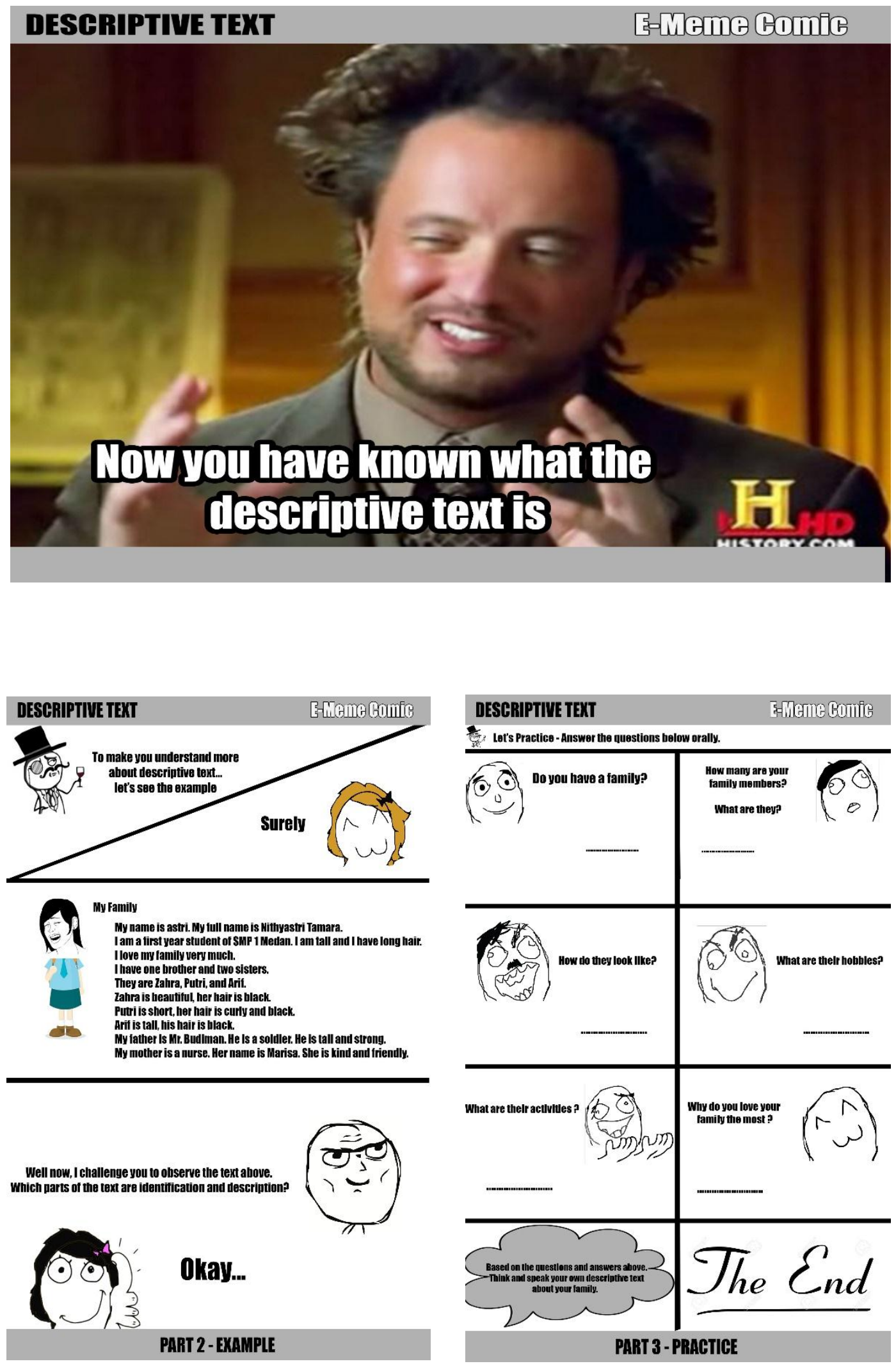


\section{CONCLUSIONS AND SUGGESTIONS}

\section{Conclusions}

After analyzing the data, the researcher draws the conclusion that the students' existing speaking media are not interesting. They find it is difficult to speak a descriptive text which eventually brings them to be passive learners. They want to have the interesting and attractive media which motivate them to learn, think and speak the descriptive text. The solution for them is developing the new interesting speaking media. These new speaking media are based on their needs and make them more interest in learning as well as ease them to think and speak a descriptive text through the meme comic.

\section{Suggestions}

Based on the above conclusions, the writer suggests that stakeholder, teacher and the students should do the need analysis regularly to meet the most appropriate and interesting media for the students. Meme comic is one of the interesting media, but teachers should make the other interesting and develop this meme comic as the students' need. In this way, the students can achieve their best achievement in speaking descriptive text. 


\section{REFERENCES}

Burns. A \& Joyce. H, (1997). Focus on Speaking. Sydney: National Center for English Language Teaching and Research.

Dawkins, R. (1989). The Selfish Gene (2 ed.) ISBN 0-19-286092-5. Oxford University Press.). h. 192.

Fulcher, G. \& Fred, D. (2007). Language testing and assessment: An advance resource book. USA : Routledge

Gall, M.D, Gall, J.P, \& Borg, W. R. (2003). Educational Research: An Introduction. $7^{\text {th }}$ Edition. Boston: Pearson Education

Gavigan, K. W. \& Tomasevich, M. (2011). Connecting Comics to Curriculum: Strategies for Grades 6- 12.Santa Barbara: ABC-CLIO, LLC.

Luoma, S. (2004), Assessing Speaking. Cambridge: Cambridge University Press

Macwan, H.J. (2015). Using Visual Aids as Authentic Material in ESL Classroom. Research Journal of English Language and Literature, Vol. 3. Issue 1.p. 91-96

Richards, J.C. (2008). Teaching Listening and Speaking: from the Theory to Practice. New York: Cambridge University Press. 